classifiable under the Minnesota code (groups VI and VII). Ten of the 19 E.C.G.s showing no codifiable abnormality exhibited one or more of the lesser signs described by Evans (1965), and a further six were found to be abnormal when compared with previous or subsequent E.C.G.s. The com-

\begin{tabular}{|c|c|c|c|c|c|c|}
\hline \multirow{2}{*}{ E.C.G. Pattern } & \multicolumn{2}{|c|}{ Episodes } & \multicolumn{4}{|c|}{$\begin{array}{l}\text { Final Diagnosis of Acute } \\
\text { Myocardial Infarction }\end{array}$} \\
\hline & Total & \begin{tabular}{|l|} 
Previous \\
Infarct
\end{tabular} & Definite & $\begin{array}{c}\text { Prob- } \\
\text { able }\end{array}$ & $\begin{array}{l}\text { Pos- } \\
\text { sible }\end{array}$ & $\begin{array}{l}\text { Ex- } \\
\text { cluded }\end{array}$ \\
\hline 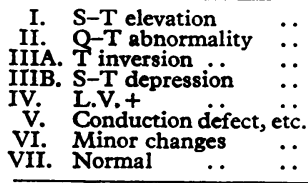 & $\begin{array}{l}19 \\
16 \\
38 \\
17 \\
27 \\
11 \\
41 \\
42\end{array}$ & $\begin{array}{r}3 \\
9 \\
14 \\
2 \\
10 \\
0 \\
9 \\
3\end{array}$ & $\begin{array}{r}19 \\
9 \\
17 \\
6 \\
7 \\
7 \\
0 \\
10 \\
9\end{array}$ & $\begin{array}{l}0 \\
1 \\
8 \\
7 \\
3 \\
3 \\
9 \\
5\end{array}$ & $\begin{array}{l}0 \\
3 \\
7 \\
1 \\
9 \\
5 \\
7 \\
5\end{array}$ & $\begin{array}{r}0 \\
3 \\
6 \\
3 \\
8 \\
3 \\
15 \\
23\end{array}$ \\
\hline & 211 & 50 & 77 & 36 & 37 & 61 \\
\hline
\end{tabular}

TABLE III.-Cause of Abnormal Electrocardiogram in Patients Without Acute Myocardial Infarction

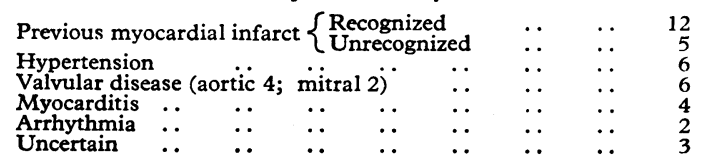

monest abnormalities were low $\mathrm{T}$ waves and slight $\mathrm{S}-\mathrm{T}$ depression, and these abnormalities were commonly combined. Three cases showed minor S-T elevation. Ten of these 19 patients subsequently developed major E.C.G. abnormalities, and one died. Nine showed no progression of the E.C.G. changes, but four of these had a significant enzyme rise.
Initial Electrocardiogram in Episodes in which Acute Myocardial Infarction was Excluded.-The E.C.G. was abnormal in 38 of the 61 episodes in which an alternative diagnosis was made. In 23 episodes it was grossly abnormal, in 15 it showed minor changes, and it was strictly normal in only 23. The causes of the E.C.G. abnormalities are shown in Table III.

\section{Conclusions}

The value of the E.C.G. in the diagnosis of suspected coronary attacks lies in the fact that a single tracing is virtually diagnostic in a proportion of cases (about $25 \%$ in this series), and serial tracings are the most useful method of confirming the diagnosis in the remainder.

The limitation of the E.C.G. lies in the fact that a single tracing recorded early in an attack of myocardial infarction frequently shows no absolutely diagnostic features, whereas in attacks not due to myocardial infarction the E.C.G. is of ten grossly abnormal on account of previous infarction or other cardiac disease.

An accurate early diagnosis of suspected coronary attacks depends on a critical evaluation of history, clinical findings, and E.C.G. The only satisfactory way of achieving this is for the doctor who reports on the E.C.G. to examine the patient himself.

\section{REFERENCES}

Blackburn, H., Keys, A., Simonson, E., Rautaharju, P., and Punsar, S. (1960). Circulation, 21, 1160

Evans, W. (1965). Brit. Heart f., 27, 856.
The continued high mortality rate of patients admitted to hospital with myocardial infarction (Honey and Truelove, 1957) has led to the introduction of coronary care units (Lawrie et al., 1967 ; Restieaux et al., 1967 ; Pentecost and Mayne, 1968 ; Thomas et al., 1968) and more recently to flying squad services (Pantridge and Geddes, 1967). Few reports have been

* General Practitioner, Southampton. published dealing with the prognosis of patients treated at home (Fry and Dillane, 1967).

This paper records the results of home treatment of patients suffering from myocardial infarction in one general practice over a four-year period.

\section{Patients}

During the four years from 1 June 1964 to 31 May 1968 50 patients were seen in one general practice in whom the diagnosis of myocardial infarction was made. Twenty-six survived the immediate period of infarction and form the main basis of this paper. The remaining 24 were dead on discovery by their relatives or dead on arrival of the family doctor. None of this latter group was suitable for resuscitation owing to the time lapse.

Nineteen of the surviving 26 patients were men aged 41 to 75 years, and seven were women aged 51 to 78 years. Eleven patients were in social class III and the remainder were evenly distributed through the other four classes. Fourteen patients had coexisting diseases (Table I).

\section{Criteria for Diagnosis}

Patients Found Dead.-In all 24 patients found dead there was a history of angina pectoris, and all had been diagnosed 
as suffering from ischaemic heart disease and were under medical supervision. Three had a history of previous myocardial infarction. Post-mortem confirmation of the cause of death was made in nine patients. In the remainder the diagnosis of myocardial infarction was made on the basis of the previous history and the description of the fatal attack by witnesses.

Table I.-Coexisting Diseases in 14 Patients

\begin{tabular}{|c|c|c|c|c|c|c|}
\hline Disease & & & $\begin{array}{l}\text { No. of } \\
\text { Cases }\end{array}$ & Disease & & \\
\hline $\begin{array}{l}\text { Hypertension } \quad \ldots \\
\text { Obesity mellitus } \\
\text { Diabetes mellit } \\
\text { Chronic bronchitis }\end{array}$ & $\begin{array}{l}\because \\
\because \\
\therefore\end{array}$ & $\begin{array}{l}\ldots \\
\cdots \\
\cdots\end{array}$ & $\begin{array}{l}6 \\
1 \\
1 \\
3\end{array}$ & $\begin{array}{l}\text { Carcinoma of lung } \\
\text { Carcinoma of prostate ... } \\
\text { Peripheral vascular disease }\end{array}$ & $\because$ & $\begin{array}{l}1 \\
1 \\
1\end{array}$ \\
\hline
\end{tabular}

Patients Surviving the Immediate Infarction.-Five patients had a previous history of a coronary thrombosis, and one had survived two attacks previous to June 1964. Seventeen patients had a history of angina pectoris for several months; in three of these it had been present for several years. Twenty-five patients suffered classical central chest pain during the infarction, and one patient had no pain but complained of lethargy and breathlessness. An initial rise in blood pressure was detected in 18 and hypotension in six. Features of congestive cardiac failure were seen in five patients and one had cardiac arrest. Electrocardiography showed evidence of an acute myocardial infarction in all patients, and this was confirmed by competent specialist opinion. Serum transaminase estimations were not performed as a routine. On a clinical basis the patients fell into two categories: six with severe pain, shock, and congestive cardiac failure, and 19 with chest pain only. Demonstrable arrhythmias were seen in only three of the shocked patients, in one of whom it was arrested. The subsequent assessment of arrhythmias was based on clinical examination during twice-daily visits in the first week of the illness.

\section{Initial Management}

All but two patients were treated at home. These two were living alone and were admitted to hospital for social reasonsone four hours after infarction and the other after eight hours, when the blood pressure had been stabilized. Twelve patients were asleep in bed at the time of infarction, and the remainder were downstairs and had been helped to bed by relatives or had gone there under their own efforts by the time the family doctor arrived.

Routine measures were taken for the control of pain. The analgesic mostly used was morphine by injection combined with chlorpromazine, and subsequently oral pethidine. Patients in failure were treated initially with digoxin, aminophylline, and frusemide intravenously, followed by oral preparations. Supportive oxygen therapy was administered to four patients in congestive cardiac failure and to one patient for relief of pain.

One patient had a cardiac arrest in the presence of the general practitioner and was restarted with two or three blows to the sternum. Artificial respiration was not necessary. Transient arrhythmia was observed subsequently in this patient and in two others; no specific measures were taken to cor:3ct this. No patient was anticoagulated.

\section{Management after First 24 Hours}

The patients were managed at home-a joint decision of patient, relatives, and family doctor. Treatment in bed was continued while the patient was in pain, but a commode was used for roilet purposes. Breathing and leg exercises were encouraged All patients were got up into a bedside chair when th" had been free of pain for 24 hours and when their blood pressure was stabilized. Initially the time spent in a chair was limited to half to one hour a day, and was then extended so that patients spent most of the day up and ambulant in the bedroom within two weeks of getting out of bed. All were downstairs within three weeks of their infarction and out of doors within six weeks, but no patient returned to work before three months.

\section{Results}

Two patients died. One, a man, died within the first 12 hours, having failed to recover from shock; this was his third infarction. The other, a woman, developed congestive cardiac failure on the fifth day and died on the seventh. One woman developed a pulmonary embolus on the tenth day of her illness and was admitted to hospital, where she made an uneventful recovery.

The remaining 23 patients were all managed at home throughout their illness and convalescence. Five had to be kept at rest in bed for 10 to 14 days, but the remainder were in a chair at the bedside within 48 hours of their infarctionincluding the woman who developed the pulmonary embolus. All made an uneventful recovery, and those who were employed at the time of their illness returned to the same work.

Of the three patients who had a demonstrable arrhythmia on E.C.G. one died and the other two survived.

Subsequent Course.-Four patients died from a further myocardial infarction between six months and two years after the original attack. All died suddenly and were beyond resuscitation by the time medical assistance became available. One patient died from disseminated malignant disease. During the month previous to the writing of this paper two patients had a myocardial infarction; the remaining 17 survived for periods up to four years (Table II). One of these had a second infarction after two years and has survived for a further six months. Two men were severely restricted by angina pectoris and unable to work, but five patients in this series had no pain on exertion.

TABLE II.-Period of Follow-up in 17 Living Patients

\begin{tabular}{l|c|c|c|c|c|c}
\hline Follow-up (Years): & $3 / 12$ & $6 / 12$ & 1 & 2 & 3 & 4 \\
\hline $\begin{array}{c}\text { No. of } \\
\text { patients }\left\{\begin{array}{l}\text { Male } \\
\text { Female }\end{array}\right.\end{array}$ & 3 & 1 & 4 & 1 & 1 & 1 \\
\hline
\end{tabular}

\section{Discussion}

From this series of 26 patients certain general conclusions can be made regarding their management at home.

Death was instantaneous or occurred before the arrival of the family doctor in 24 of the 50 patients. This represents $48 \%$ of the total compared with $14 \%$ in the general practice survey of Fry and Dillane (1967). Any improvement in the mortality rate is unlikely within this group of patients. However, it is in those who survive the immediate period of infarction that the efficiency of treatment should be judged and where improvements in mortality rate can be expected. In this series $7 \%$ of patients died after surviving the period of infarction, $33 \%$ in the study by Fry and Dillane, and according to various reports between 14 and $40 \%$ in hospital patients (Rosenbaum and Levine, 1941; Mintz and Katz, 1947 ; Billings et al., 1949 ; Doscher and Poindexter, 1950 ; Honey and Truelove, 1957 ; Killip, 1966 ; Norris et al., 1968). Within this group arrhythmias are the main treatable cause of death, and it is here that specialized coronary care units and the mobile intensive care units, as suggested by Pantridge and Geddes (1967), have their advantage.

Observed arrhythmias were seen in only three patients in this study, though other episodes may have occurred in these and other patients. One of those who showed an arrhythmia died, 
but might have benefited from admission to a specialized unit. The occurrence of arrhythmias was not a marked feature of this series, and this may be the reason for the low mortality rate in those who survived the initial period of infarction. The stress of awaiting the ambulance, the journey often down steep and narrow stairs, and the subsequent ride to hospital may predispose to arrhythmias and contribute to the high mortality rate seen in the first few hours after admission. The advantage of treatment at home, particularly in the early stages, is that it avoids the moving of an ill patient to hospital under difficult circumstances. If poor social conditions necessitate transfer for treatment it would seem reasonable to delay until pain and shock are controlled.

Adequate explanation of the cause and effect of the illness, and the management in the first month, are required if relatives are to be asked to co-operate. In this series none objected to treatment at home, and most welcomed it. Frequent visiting by family doctor and district nurse is necessary in the first few days ; this ensures the well-being of the patient and gives reassurance to the helping relatives. The provision of a home help and a night attendant, when necessary, ensured that no family was subjected to excessive strain.

The use of a bedside commode was appreciated and did not seem to affect the patient's recovery. As a result constipation was not a feature of this study. Breathing and leg exercises were implemented from an early stage. Such limited activity was taken by both patient and relatives to be a sign of improvement and had a beneficial effect on morale.
No patient was given anticoagulants as a routine, but the development of a pulmonary embolus in one patient might have been prevented had such a prescription been given.

During this four-year study those patients who were treated at home have appreciated this form of management. No relatives, after explanation of what home care entails, have objected to caring for the patient in his own house. It is felt that patients so treated have more rest and less upset than those admitted to hospital, and this may help in their recovery.

I am indebted to Dr. Richard Buckle, consultant physician, Southampton General Hospital, for his advice on the preparation of this paper.

\section{REFERENCES}

Billings, F. T., jun., Kalstone, B. M., Spencer, J. L., Ball, O. T., and Meneely, G. R.' (1949). Amer. ₹. Med., 7, 356

Doscher, N., and Poindexter, C. A. (1950). Amer. F. Med., 8, 623.

Fry, J., and Dillane, J. B. (1967). f. roy. Coll. gen. Practit., 14, 44.

Honey, G. E., and Truelove, S. C. (1957). Lancet, 1, 1155.

Killip, T. (1966). In The Current Status of Intensive Coronary Care. New York.

Lawrie, D. M., et al. (1967). Lancet, 2, 109.

Mintz, S. S., and Katz L. N. (1947). Arch. intern. Med., 80, 205.

Norris, R. M., Caughey, D. E., and Scott, P. J. (1968). Brit. med. f., 2, 398.

Pantridge, J. F., and Geddes, J. S. (1967). Lancet, 2, 271

Pentecost, B. L., and Mayne, N. M. C. (1968). Brit. med. 7., 1, 830

Restieaux, N., et al. (1967). Lancet, 1, 1285.

Rosenbaum,F. E., and Levine, S. A. (1941). Arch. intern. Med., 68, 913.

Thomas, M., Jewitt, D. E., and Shillingford, J. P. (1968). Brit. med. F., 1,787 .

\title{
Vasopressin in Prevention of Lumbar Puncture Headache
}

\author{
HASAN AZIZ,* M.B., B.SC., M.R.C.P.ED. ; JOHN PEARCE, † M.D., M.R.C.P. ; E. MILLER, $\ddagger$ B.SC., M.PHIL.
}

\begin{abstract}
Summary : A double-blind controlled trial of aqueous vasopressin injection (Pitressin) in the prophylaxis of lumbar puncture reactions in 50 patients showed that the incidence of reactions was unaffected, but that severe reactions occurred less frequently in the treatment group. Moderately severe side-effects occurred in $27 \%$ of those receiving vasopressin.
\end{abstract}

\section{Introduction}

Unpleasant reactions to lumbar puncture consisting of headache, nausea, and vomiting are common in clinical practice. Their incidence is partly dependent on the skill and experience of the person performing the lumbar puncture, but even in the best hands reactions occur despite apparently atraumatic punctures of the theca. Though no drug has yet proved to be capable of preventing such reactions, the use of vasopressin injection (Pitressin) as a prophylactic was in vogue some years ago but was never subjected to critical analysis. The impressions and experience of a number of clinical neurologists were obtained by postal survey, and opinions concerning the efficacy of vasopressin injection in lumbar puncture headache prophylaxis varied from " ineffective" to " usually effective." Because of the variation of clinical impression a controlled trial was undertaken.

* Registrar in Neurology.

† Consultant Neurologist, Hull Royal Infirmary.

$\ddagger$ Lecturer in Psychology, Hull University ; Clinical Psychologist, Combined Neurological Service, Hull Royal Infirmary.

\section{Material and Methods}

Fifty consecutive unselected patients in the Combined Neurological Service of the Hull Royal Infirmary requiring a lumbar puncture for diagnostic purposes were studied. They were allocated by one of us (E. M.) (not involved in clinical care) by random numbers to one of two groups-treated and control. Identical $1-\mathrm{ml}$. ampoules containing respectively 20 units of aqueous vasopressin injection and isotonic saline were dispensed by the pharmacy according to the random numbers.

After lumbar puncture the patients were advised to rest in bed lying on one pillow for 24 hours. The word headache was not mentioned by nursing or medical staff, but simple analgesics were given on request of the patient when necessary.

Each patient was given 1 ampoule of vasopressin injection or placebo intramuscularly immediately after lumbar puncture and then 12-hourly for 48 hours. The reaction to lumbar puncture was assessed 24 and 48 hours after the procedure, care being taken not to suggest or minimize symptoms. Sideeffects were carefully recorded. Each assessment was made jointly by two clinicians and arbitrarily scored as follows: grade 1, no headache, sickness, or other symptoms; grade 2 , headache alone, lasting less than 24 hours; grade 3, headache for 24 to 48 hours with or without nausea or vomiting; and grade 4 , severe headache and/or vomiting lasting longer than 48 hours.

\section{Results}

The numbers and percentages of patients falling, into each grade are shown in Table I. The difference between the 